I wish especially to express my thanks to Dr. Kekwick and to the Lister Institute for the facilities they placed at my disposal.

St. George's Hospital,

Hyde Park Corner,

London, S.W.1. April 2.

'MacLagan, N. F., Brit. J. Exp. Path., 25, 234 (1944).

'Hangar, F. M., Conference on Liver Injury, New York (1946).

- MacLagan, N. F., and Bunn, D., Biochem. J., 41, 580 (1947).

- Kunkel, H., and Hoagland, C. L., J. Clin. Invest., 26, 1060 (1947)

Maclagan, N. F., Proc. Biochem. Soc. (in the press).

'Martin, N. H., Brit. J. Exp. Path., 27, 363 (1946).

\section{N-Diethylaminoethylphenothiazine : a Specific Inhibitor of Pseudocholinesterase}

Mendel and Rudney ${ }^{1}$ demonstrated that mammalian tissues may contain two distinct esterases, both capable of hydrolysing acetylcholine in vitro: a specific enzyme ('true' cholinesterase) and a nonspecific enzyme ('pseudo'cholinesterase). The chemically dissimilar natures of the two enzymes were indicated by their selective behaviour towards particular choline esters ${ }^{2}$ and by the selective toxic effects, on the pseudo esterase, of the dimethylcarbamate of (2-hydroxy : 5-phenylbenzyl)-trimethylammonium bromide ${ }^{3}$ and of diisopropylfluorophosphate ${ }^{4}$. Both these substances exert powerful effects on pseudocholinesterase at concentrations which are relatively ineffective against true cholinesterase.

Experiments recently recorded in these laboratories indicate another organic compound which exerts a similar selective toxic action on pseudocholinesterase. The compound N-diethylaminoethylphenothiazine hydrochloride (also known as 2987 R.P.), of the following constitution :

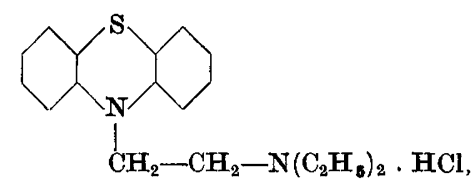

was originally synthesized by Gilman and Shirley and first examined pharmacologically by Bovet et al. ${ }^{6}$ in connexion with its possible use in the symptomatic treatment of Parkinson's disease. It was tested for anticholinesterase activity, using the technique of Ammon?. The source of enzyme was either a rat brain extract, which is believed to contain only true cholinesterase $^{8}$, or blood plasma. The brain extract was prepared by grinding a whole rat brain with sand and normal saline, filtering through muslin, and diluting the filtrate with saline to a final volume of $8 \mathrm{ml}$. per gm. original tissue. Enzyme activities were measured at $37^{\circ} \mathrm{C}$., using as substrates acetylcholine, acetyl- $\beta$-methylcholine (mecholyl) and benzoylcholine, in presence of various concentrations of 2987 R.P., and measurements of carbon dioxide output in every case were made for a period of $1 \mathrm{hr}$. after equilibration. Controls without drug and without substrate were also set up. Typical results are shown in the table.

It will be seen that, while the activity of pseudocholinesterase, indicated by the action of plasma on benzoylcholine, is strongly inhibited by $2987 R . P$. at

\begin{tabular}{|c|c|c|c|}
\hline Source of enzyme & $\begin{array}{l}\text { Concentration } \\
\text { of substrate }\end{array}$ & $\begin{array}{l}\text { Concentration } \\
\text { of } 2987 R . P .\end{array}$ & $\begin{array}{l}\text { \% } \\
\text { Inhibition } \\
\text { of enzyme }\end{array}$ \\
\hline $0.5 \mathrm{ml}$. brain & $0.007 M$ acetyl- & & \\
\hline $0.5 \mathrm{ml}$. rat plasma & $0.007 M$ & $3 \cdot 0 \times 10^{-4} M$ & $9 \cdot 2$ \\
\hline $0.5 \mathrm{ml}$. rat plasma & $0.006 \mathrm{M}$ benzoyl- & $0.24 \times 10^{-4} M$ & $74 \cdot 0$ \\
\hline $0.3 \mathrm{ml} . \underset{\text { plasma }}{\text { guinea pig }}$ & $\begin{array}{c}0.006 M \text { benzoyl- } \\
\text { choline }\end{array}$ & $0.075 \times 10^{-4} \mathrm{M}$ & $87 \cdot 3$ \\
\hline
\end{tabular}

concentrations of the order of $0.075 \times 10^{-4} M$ and $0 \cdot 24 \cdot \times 10^{-4} M$, the activity of the true cholinesterase, indicated by the action of brain extract on acetylcholine and of plasma on mecholyl, is not affected appreciably by the drug even at much greater concentrations, of the order of $5 \cdot 1 \times 10^{-4} M$.

The results are in harmony with the views expressed by Mendel et al. ${ }^{1,2}$ regarding the chemically distinct natures of the two types of cholinesterase.

Biological Division, J. J. GoRDON*

May and Baker, Ltd.

Dagenham, Essex.

March 19.

* Present address: Research Department, Bristol Mental Hospital, Fishponds, Bristol.

${ }^{1}$ Mendel and Rudney, Biochem. J., 37, 59 (1943).

2 Mendel, Mundell and Rudney, Biochem. J., 38, 473 (1944).

${ }^{3}$ Hawkins and Gunter, Biochem. $J ., 40,192$ (1946).

'Mendel and Hawkins, Biochem. J., 41, xxii (1947).

${ }^{5}$ Gilman and Shirley, J. Amer. Chem. Soc., 66, 888 (1944).

- Bovet, Fournel and Charpentier, Therapie, 2, 115 (1947).

"Ammon, Arch. ges. Physiol., 233, 486 (1933).

${ }^{8}$ Mendel and Rudney, Science, 98, 201 (1943).

\section{Metachloridine-substituted Aryl Biguanides as Possible Antimalarial Compounds}

METANILAmIDEs are reported to have no antibacterial action ${ }^{1}$, and from the parallel nature of the antimalarial and antibacterial properties of sulphanilamides, discouraged research in the field of metanilamides as possible antimalarials. Recently, English et $a l .^{2}$ discovered enhanced antimalarial activity in 2-sulphanilamido-5-chloropyrimidine, and their work resulted in the discovery of metachloridine ${ }^{3}$ ( $S N$ 11437) (2-metanilamido-5-chloropyrimidine), which has been found to be effective both in avian ${ }^{3}$ and human malarias ${ }^{4,5,6}$. Metachloridine is 5-chloropyrimidine-substituted metanilamide, the action of which is not affected by the presence of $p$-aminobenzoic acid, and is supposed ${ }^{3}$ to have a double mode of action due to the presence of 5-chloropyrimidine and metanilamide parts in the molecule.

Previously, sulpha-biguanides of type $(A)$, some of which have shown encouraging antimalarial activity against avian malaria ( $P$. gallinaceum), have been reported by $\mathrm{us}^{7,8}$. The following compounds of type $(B)$ have also been prepared (see table), where metachloridine forms the $\mathrm{N}^{5}$-substituent of $N^{1}$-arylbiguanides.

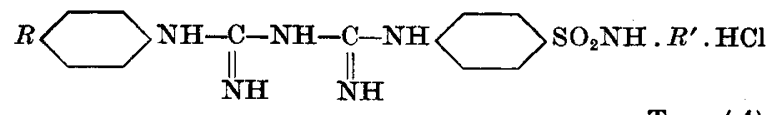

Type $(A)$

$R=\mathrm{H}, \mathrm{Cl}, \mathrm{Br}, \mathrm{NO}_{2}, \mathrm{CH}_{3}$, etc.

$R^{\prime}=\mathrm{H}$, 2-thiazolyl, 2-pyrimidyl, $4: 6$-dimethyl-2pyrimidyl, 6-methyl-2-pyrimidyl. 